Огляди літератури, оригінальні дослідження, погляд на проблему, ювілеї

УДК 615.453.+616.001.14+577.1:616.379-008.64

DOI 10.11603/1811-2471.2018.v0.i3.9284

\title{
ВПЛИВ КЕЛТІКАНУ ТА ПОЛЯРИЗУЮЧОГО СВІТЛА НА ПОКАЗНИКИ ПЕРЕКИСНОГО ОКИСНЕННЯ ЛІПІДІВ ТА АНТИОКСИДАНТНОГО ЗАХИСТУ У ХВОРИХ НА ЦУКРОВИЙ ДІАБЕТ 2 ТИПУ 3 ДІАБЕТИЧНОЮ ПОЛІНЕЙРОПАТІЄЮ ТА ДИСЛІПІДЕМІЄЮ
}

\section{๑Л. П. Мартинюк, Н. Р. Макарчук \\ ДВНЗ «Тернопільський державний медичний університет імені І. Я. Горбачевського МОз України»}

РЕЗЮМЕ. У хворих на цукровий діабет (ЦД) 2-го типу відбувається порушення процесів перекисного окиснення ліпідів, внаслідок чого порушується нормальне функціонування мембранних структур клітин, посилюється їх деструкція, а це може бути фактором прогресування такого ускладнення, як діабетична полінейропатія (ДПН).

Метою дослідження було вивчення впливу комплексного лікування препаратом Келтікан та поляризуючим світлом на показники ПОЛ та АОЗ у хворих на цукровий діабет 2 типу з діабетичною полінейропатією і дисліпідемією.

Матеріал і методи дослідження. Обстежено 130 хворих на ЦД 2-го типу, ускладнений діабетичною полінейропатією. Пацієнти були поділенні на 4 групи: до 1 групи увійшли 32 пацієнти, які отримували стандартне лікування, 32 хворих 2 групи додатково отримували келтікан по 1 капсулі тричі на добу впродовж місяця. 35 діабетикам 3 групи додатково було призначено 12 лікувальних процедур поляризуючим світлом. 31 пацієнт 4 групи, окрім стандартного лікування, отримував келтікан та курс світлотерапевтичних процедур поляризуючим світлом одночасно.

Стан ПОЛ оцінювали за вмістом дієнових кон'югатів (ДК) і малонового діальдегіду (МДА). Активність антиоксидантного захисту (АОЗ) вивчали за концентрацією супероксиддисмутази (СОД), каталази та глутатіону відновленого (SH-група).

Для оцінки стану ліпідного обміну визначали рівні ХС (холестерину), фракцій лпВщ (ліпопротеїди високої щільності), лпнщ (ліпопротеїди низької щільності) і ТГ (тригліцериди).

Результати. Включення до стандартного лікування ДПН келтікану та поляризуючого світла має більш виражений вплив на показники ПОЛ та АОЗ, порівняно з стандартним лікуванням. Результати ліпідограми найбільше наближені до цільового рівня під впливом лікування у 4 групи.

Висновок. Включення до стандартної терапії ДПН у хворих з цукровим діабетом 2 типу і дисліпідемією препарату Келтікан та світлотерапевтичних процедур мало корегуючий вплив на показники ПОЛ і АОЗ.

КЛючОВІ СлОВА: діабетична полінейропатія; оксидативний стрес; ліпідний обмін; келтікан; поляризуюче світло.

Вступ. Порушення динамічної рівноваги в системі перекисного окиснення ліпідів (ПОЛ) та антиоксидантного захисту (АОЗ) призводить до розвитку оксидантного стресу (ОС), який $\epsilon$ невід'ємною складовою патогенезу цукрового діабету (ЦД) 2 типу та його специфічних і неспецифічних ускладнень [2-6]. Активація процесів вільнорадикального окиснення за умов поступового виснаження резервів антиоксидантного захисту організму супроводжується посиленням деструктивних процесів і збільшенням тяжкості перебігу захворювань.

Ускладнення, що розвиваються при ЦД 2 типу, супроводжуються вільнорадикальною патологією [7-10], зокрема, доведена роль надлишкового утворення вільних радикалів у розвитку діабетичної полінейропатії (ДПН) [11].

При цьому незалежно від ступеня компенсації вуглеводного обміну, наявний зв'язок між інтенсивністю вільнорадикального окиснення, дисліпідемією та тригліцеридемією, які, у свою чергу, згубно впливають на функціонування клітин [12, 13]. ПОЛ, у свою чергу, гальмує утворення ліпопротеїнів високої щільності $[14,15]$.

Отримані дані щодо позитивного клінічного впливу препарату Келтікан та поляризуючого сівтла на перебіг ДПН $[16,17]$ спонукали вивчити їх вплив на ПОЛ та АO3, як один із патогенетичних механізмів розвитку ДПН.

Мета дослідження - оцінити зміни ПОЛ та АОЗ під впливом лікування із використанням поляризуючого світла та препарату Келтікан у хворих 3 діабетичною полінейропатією і дисліпідемією.

Матеріал і методи дослідження. Було обстежено 130 хворих на ЦД 2 типу, з дисліпідемією та діабетичною полінейропатію. Вік обстежених становив від 45 до 65 років (середній вік $(56,46 \pm 5,79)$ роки). Тривалість ЦД склала від 5 до 21 року (середня тривалість $(9,81 \pm 3,85)$ роки), а ДПН - 1-13 років (середня тривалість $(5,55 \pm 2,94)$ роки). Серед обстежених було 64 (49,23 \%) чоловіки і 66 (50,77 \%) жінок.

Усі обстежені були поділені на 4 групи: до 1 групи увійшли 32 пацієнти, які отримували стандартне лікування згідно з Уніфікованим клінічним протоколом первинної та вторинної (спеціалізованої) медичної допомоги (№ 1118 від 21.12.2012) [18]. 32 пацієнти 2 дослідної групи додатково отримували препарат Келтікан (цитидину-5'-динатрію монофосфату 5,0 мг; уридину-5'тринатрію трифосфату, уридину-5'-динатрію ди- 
Огляди літератури, оригінальні дослідження, погляд на проблему, ювілеї

фосфату, уридину-5'-динатрію монофосфату) в дозі, еквівалентній 1,330 мг уридину, - по 1 капсулі тричі на добу впродовж одного місяця. 3 групу склали 35 хворих, до лікування яких було включено 12 лікувальних процедур з використанням поляризуючого світла. 31 пацієнт 4 групи, окрім стандартного лікування, отримував келтікан та курс поляризуючого світла одночасно. Контрольну групу для порівняння показників ПОЛ, АОЗ та ліпідограми склали 20 практично здорових осіб, донорів з пункту переливання крові.

Групи були зіставними за віком, тривалістю ЦД та вираженням клінічних проявів ДПН (табл. 1).

Таблиця 1. Загальна характеристика хворих на цукровий діабет 2 типу $(\mathrm{M} \pm \sigma)$

\begin{tabular}{|l|c|c|c|c|c|c|}
\hline \multicolumn{1}{|c|}{ Характеристика } & $\begin{array}{c}1 \text { група } \\
\mathrm{n}=32\end{array}$ & $\begin{array}{c}2 \text { група } \\
\mathrm{n}=32\end{array}$ & $\begin{array}{c}3 \text { група } \\
\mathrm{n}=35\end{array}$ & $\begin{array}{c}4 \text { група } \\
\mathrm{n}=31\end{array}$ & $\mathrm{~F}$ & $\mathrm{P}$ \\
\hline Вік, роки & $58,656 \pm 5,200$ & $55,531 \pm 6,749$ & $55,6 \pm 4,858$ & $56,129 \pm 5,96$ & 2,15 & $\mathrm{p}>0,05$ \\
\hline Тривалість ЦД, роки & $8,563 \pm 3,252$ & $10,125 \pm 3,842$ & $10,086 \pm 4,01$ & $10,581 \pm 3,965$ & 1,72 & $\mathrm{p}>0,05$ \\
\hline Тривалість ДПН, роки & $4,906 \pm 2,821$ & $5,188 \pm 2,912$ & $6,0 \pm 3,077$ & $6,065 \pm 2,898$ & 1,27 & $\mathrm{p}>0,05$ \\
\hline
\end{tabular}

Діагноз ДПН встановлювали відповідно до уніфікованого клінічного протоколу первинної та вторинної (спеціалізованої) медичної допомоги (№ 1118 від 21.12.2012).

Стан ПОЛ оцінювали за вмістом дієнових кон'югатів (ДК) і малонового діальдегіду (МДА). Активність антиоксидантного захисту (АОЗ) вивчали за концентрацією супероксиддисмутази (СОД), каталази та глутатіону відновленого (SH-група), які визначали за методиками: ДК - спектрофотометричним методом; МДА - спектрофотометричним методом з 2-тіобарбітуровою кислотою (ТБК); СОД - спектрофотометричним методом; каталазу - кількісним методом (визначення кількості преоксиду водню, перетвореного ензимом за певний проміжок часу); SH-групи - спектрофотометричним методом (при 412 нм).

Для оцінки стану ліпідного обміну визначали рівні ХС (холестерину), фракцій лПВЩ (ліпопротеїди високої щільності), лпнщ (ліпопротеїди низької щільності) і ТГ (тригліцериди) за загальноприйнятими методиками.

Вміст ХС визначали за методом Ілька із застосуванням реактивів виробництва «Філісіт діагностика», Україна. Вивчення концентрації лПВЩ проводили за допомогою реактивів ELI-TECH diagnostics ензиматичним методом. Колориметричний метод використовували для визначення рівня ТГ (реактиви PLIVA-Lachema, Чеська Респу6ліка).

Визначення ЛПНЩ проводили шляхом визначення на колориметрі ступеня помутніння розчину, який утворюється при осадженні лпнщ в присутності хлориду кальцію і гепарину.

Фракції холестерину лПнЩ розраховували за формулою W. Friedwald: ЛПНЩ = 3ХС - ( ЛПВЩ+ $\mathrm{T} \Gamma / 2,2)$.

Аналіз й обробку статистичних даних клінічних обстежень проводили на персональному комп'ютері з використанням пакета прикладних програм STATISTICA 10 та MS Excel XP порівняння між групами проводили за допомогою дисперсного аналізу, порівняння середніх рангових у групі проводили за допомогою непараметричного методу Вілкоксона і вважали їх достовірними при $p<0,05$. Кореляційні зв'язки оцінювали парними кореляціями.

Результати й обговорення. У досліджуваних групах пацієнтів із ЦД 2 типу та ДПН достовірної різниці між показниками ПОЛ та АОЗ до лікування виявлено не було (рис. 1). Проте, порівняння з показниками контрольної групи показало вірогідні відмінності $(p<0,05)$ активності ПОЛ, а саме рівень МДА був збільшений у 3 рази; ДК - у 1,5 раза. АОЗ: кількість SH-груп зменшена у 3 рази, СОД менша в 1,5 раза у всіх пацієнтів із даною патологією; каталаза підвищена у 3 рази, порівняно з контролем.

Встановлено підвищену активність ПОЛ, а саме МДА і ДК, та зниження рівня показників АОЗ (СОД, каталази та SH-групи).

Проведене лікування сприяло достовірному покращенню показників ПОЛ та АОЗ всередині досліджуваних груп пацієнтів (рис. 2).

Аналіз кожного із показників ПОЛ окремо виявив певну різницю отриманих результатів, що залежало від способу лікування (табл. 2).

Так, рівні МДА і ДК достовірно різнилися до і після лікування всередині усіх груп хворих, проте порівняння отриманих результатів між групами показало, що у хворих, які додатково отримували келтікан та поляризуюче світло, показники були вірогідно нижчими, ніж у інших трьох групах пацієнтів, а показник ДК досяг контрольного рівня.

При цьому використання у комплексній терапії келтікану або поляризуючого світла показало вірогідну відмінність з пацієнтами, які отримували лише стандартну терапію, за даними показника ПОЛ.

Отримано аналогічні позитивні результати впливу лікування на показники $\mathrm{AO}$ всередині кожної з досліджуваних груп $(p<0,01)$. 


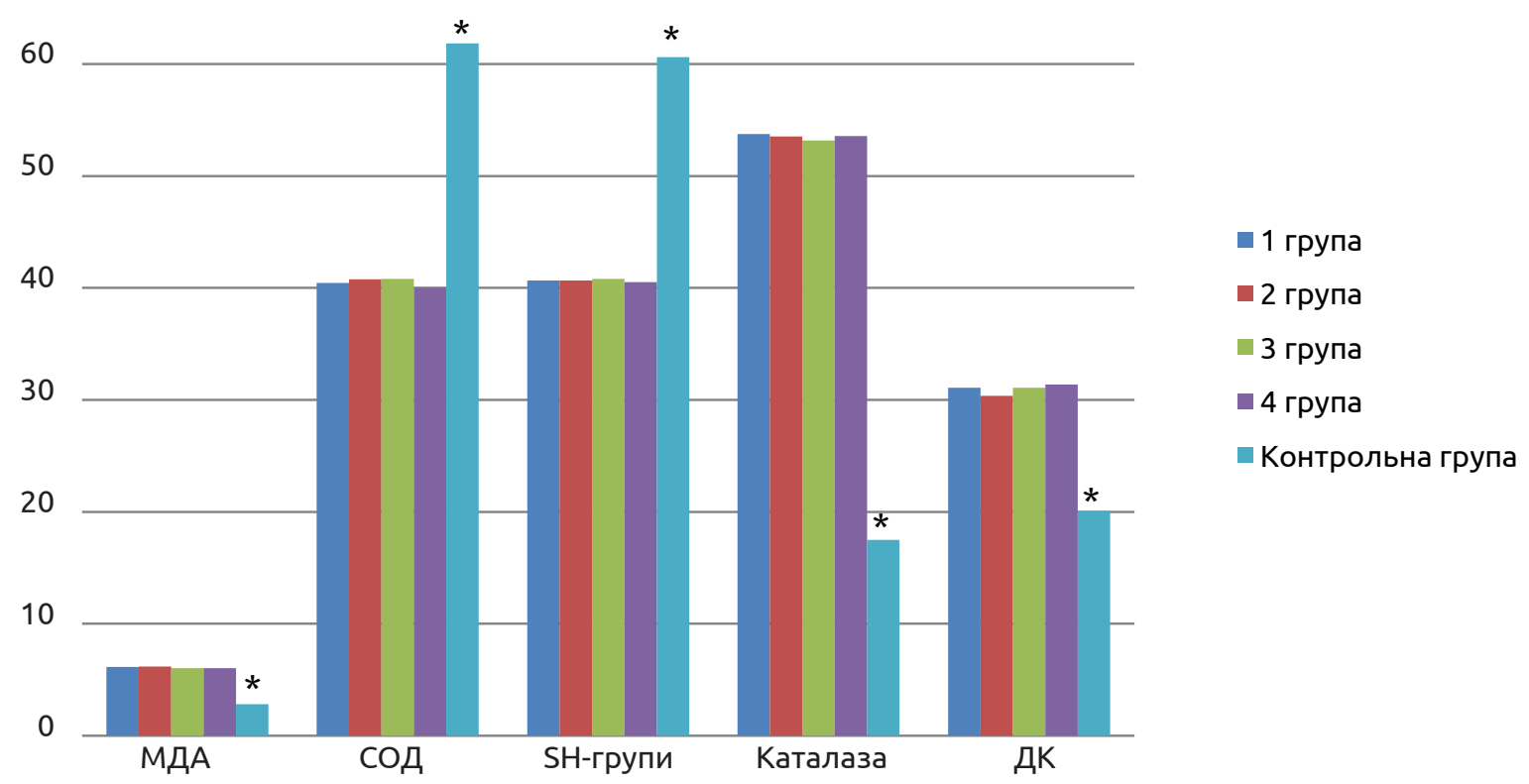

Рис. 1. Результати порівняння показників ПОЛ та АОЗ хворих досліджуваних груп до лікування. Примітки: 1. * - p<0,05 між хворими КГі досліджуваними групами; 2. ** - p<0,05 між групами пацієнтів.
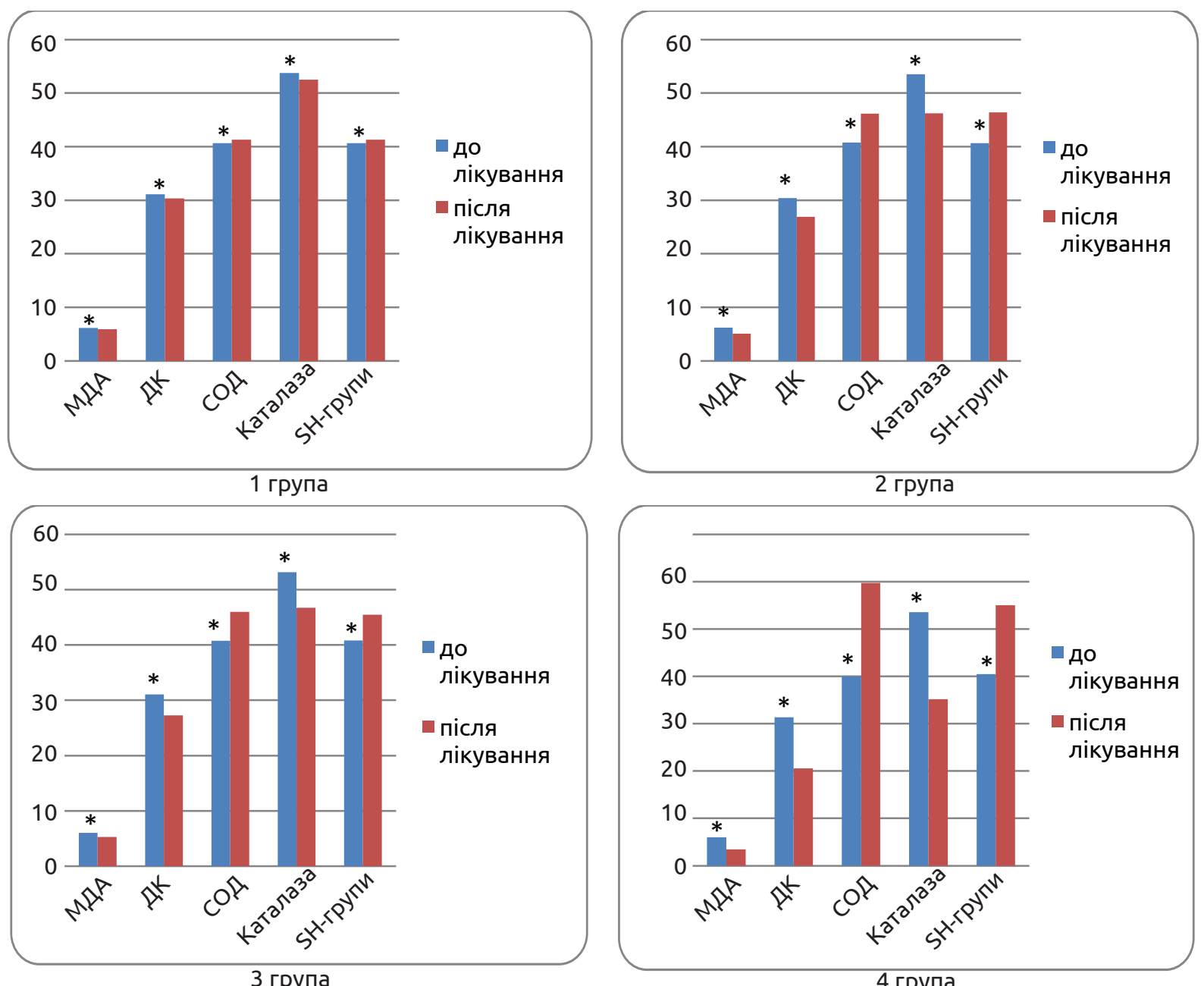

Рис. 2. Результати порівняння показників пОЛ та АОЗ хворих всередині досліджуваних груп до та після лікування.

Примітка. * - p<0,05 між хворими в групі до та після лікування. 
Огляди літератури, оригінальні дослідження, погляд на проблему, ювілеї

Таблиця 2. Динаміка показників ПОЛ у пацієнтів із ЦД 2 типу та діабетичною полінейропатією після лікування залежно від застосованих схем лікування, $(M \pm \sigma)$

\begin{tabular}{|c|c|c|c|c|c|c|c|}
\hline Показник & $\begin{array}{c}\text { Контрольна } \\
\text { група } \\
(n=20)\end{array}$ & $\begin{array}{c}1 \text { група } \\
(n=32)\end{array}$ & $\begin{array}{c}2 \text { група } \\
(n=32)\end{array}$ & $\begin{array}{c}3 \text { група } \\
(n=35)\end{array}$ & $\begin{array}{c}4 \text { група } \\
(n=31)\end{array}$ & $\begin{array}{c}\text { F-кри- } \\
\text { терій } \\
\text { Фішера }\end{array}$ & $P$ \\
\hline $\begin{array}{l}\text { МДА } \\
\text { нмоль/л }\end{array}$ & $2,81 \pm 0,10$ & $5,94 \pm 0,694, \mathrm{~K} \Gamma$ & $5,10 \pm 1,574, \mathrm{k} \Gamma$ & $5,30 \pm 1,32 \frac{4, \mathrm{~K} \Gamma}{}$ & $3,43 \pm 1,16$ 1,2,3, $\mathrm{kr}$ & 23,63 & 0,001 \\
\hline $\begin{array}{l}\text { ДК } \\
\text { мКмоль/л }\end{array}$ & $20,1 \pm 0,69$ & $30,31 \pm 2,46^{2,3,4, \mathrm{~K} \Gamma}$ & $26,90 \pm 3,48^{1,4, \mathrm{~K} \Gamma}$ & $27,28 \pm 2,691.4, \mathrm{kr}$ & $20,54 \pm 2,56 \underline{1,2,3}$ & 66,30 & 0,001 \\
\hline $\begin{array}{l}\text { SH-групи, } \\
\text { млмоль/л }\end{array}$ & $60,60 \pm 0,21$ & $41,29 \pm 1,96 \underline{2.3 .4, \mathrm{~K} \Gamma}$ & $46,37 \pm 7,95 \frac{1.4, \mathrm{kr}}{}$ & $45,49 \pm 6,344.1, \mathrm{kr}$ & $55,04 \pm 6,58 \stackrel{1,2,3, \mathrm{~K} \Gamma}{ }$ & 27,77 & 0,001 \\
\hline $\begin{array}{l}\text { Каталаза, } \\
\text { \% }\end{array}$ & $17,50 \pm 0,08$ & $52,52 \pm 5,16 \frac{4 . \mathrm{Kr}}{\mathrm{K}}$ & $46,25 \pm 4,084, \mathrm{~K} \Gamma$ & $46,75 \pm 11,87$ 4.KГ & $35,21 \pm 13,83 \frac{1,2,3, \mathrm{Kr}}{}$ & 11,83 & 0,001 \\
\hline $\begin{array}{l}\text { СОД, } \\
\%\end{array}$ & $61,86 \pm 0,37$ & $41,07 \pm 2,72 \frac{4.2,3, \mathrm{kr}}{}$ & $46,19 \pm 7,89^{1,4, \mathrm{kr}}$ & $45,99 \pm 5,83^{1,4, \mathrm{~K} \Gamma}$ & $59,75 \pm 8,381,2,3$ & 46,95 & 0,001 \\
\hline
\end{tabular}

Примітки: 1. X 1.2.3.4.кг - р<0,01 достовірність різниці показників між різними групами після лікування.

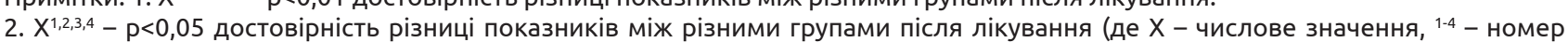
групи).

3. КГ - контрольна група.

Встановлено вірогідне підвищення рівнів СОД і SH-груп у пацієнтів 2, 3 та 4 груп, відносно 1 групи, і рівня каталази у хворих 4 групи, порівняно з іншими трьома групами обстежених; у пацієнтів цієї ж групи вдалося досягти контрольних рівнів показника СОД.

Підсумовуючи отримані дані слід вказати на достовірне покращення показників ПОЛ та АОЗ у всіх групах після лікування.

Міжгруповий аналіз показав вірогідну різницю між показниками у групах пацієнтів залежно від запропонованої схеми проведеної терапії.

Включення до стандартного лікування ДПН келтікану та поляризуючого світла має більш ви- ражений вплив на показники ПОЛ та АO3, порівняно зі стандартним лікуванням.

До початку лікування у хворих досліджуваних груп спостерігали збільшення концентрації в крові ХС, ЛПНЩ, ТГ, зменшення вмісту ЛПВЩ. Початкові показники ліпідограми в групах обстежених пацієнтів були зіставними (p>0,05) і відрізнялися від цільового рівня (рис. 3).

Під впливом запропонованого нами лікування зміни ліпідограми були наступними: холестерин достовірно відрізнявся у 4 групі, порівняно з 1 та 2 групами. ЛПНЩ вірогідно відрізнялися між 2 та 4 групами, такий же результат був між 1 та 4 групами при порівнянні ТГ. ЛПВЩ достовірно не відрізнялися в жодній з груп (табл. 3).

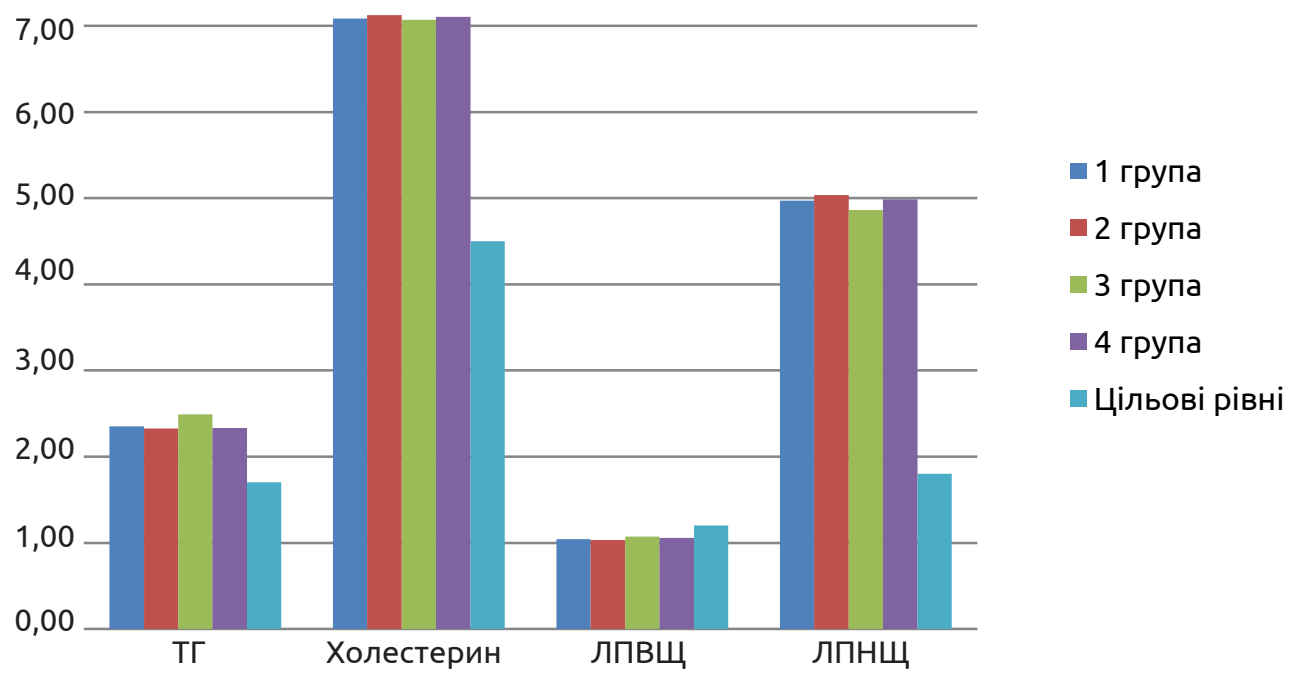

Рис. 3. Результати показників ліпідограми хворих досліджуваних груп до лікування. Примітка. 1. * - р<0,05 між досліджуваними групами. 
Огляди літератури, оригінальні дослідження, погляд на проблему, ювілеї

Таблиця 3. Динаміка показників ліпідного обміну у пацієнтів із ЦД 2 типу та діабетичною полінейропатією

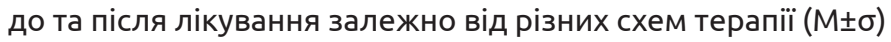

\begin{tabular}{|c|c|c|c|c|c|c|c|}
\hline \multirow{2}{*}{ Показник } & \multicolumn{6}{|c|}{ Групи } & \multirow{2}{*}{$\begin{array}{c}\begin{array}{c}\text { Дисперсійний } \\
\text { аналіз }\end{array} \\
\mathrm{P}\end{array}$} \\
\hline & $\begin{array}{l}\text { цільові } \\
\text { рівні }\end{array}$ & $1(n=32)$ & $2(n=32)$ & $3(n=35)$ & $4(n=31)$ & $\begin{array}{l}\text { F-критерій } \\
\text { Фішера }\end{array}$ & \\
\hline $\begin{array}{l}\text { Холестерин, } \\
\text { ммоль/л }\end{array}$ & $<4,5$ & $6,12 \pm 1,074$ & $6,30 \pm 1,034$ & $5,82 \pm 1,09$ & $5,39 \pm 1,16 \underline{1,2}$ & 5,01 & 0,001 \\
\hline лПНЩ, ммоль/л & $<1,8$ & $4,07 \pm 1,15$ & $4,34 \pm 1,084$ & $3,89 \pm 1,23$ & $3,51 \pm 0,84^{2}$ & 3,13 & 0,001 \\
\hline лПВЩ, ммоль/л & $>1,2$ & $1,13 \pm 0,17$ & $1,14 \pm 0,11$ & $1,14 \pm 0,12$ & $1,17 \pm 0,09$ & 0,48 & 0,695 \\
\hline $\begin{array}{l}\text { Тригліцериди, } \\
\text { ммоль/л }\end{array}$ & $<1,7$ & $2,01 \pm 0,734$ & $1,79 \pm 0,58$ & $1,71 \pm 0,70$ & $1,55 \pm 0,701$ & 2,51 & 0,061 \\
\hline
\end{tabular}

Примітки. 1. * - достовірність різниці показників у групі, до і після лікування $(p<0,01)$;

2. Xㄴ,2,3,4 - достовірність різниці показників між різними групами після лікування $(p<0,01)$;

3. $\mathrm{X}^{1,2,3,4}$ - достовірність різниці показників між різними групами після лікування (де $\mathrm{X}-4$ чслове значення, ${ }^{1-4}-$ номер групи) (р<0,05).

Найбільше наближені до цільового рівня результати були у 4 групі.

Проведений аналіз кореляційних зв'язків між показниками ПОЛ (ДК, МДА), АОЗ (SH-групи, СОД, каталаза) та даними ліпідограми (ЛПВЩ, лПНЩ, ТГ, холестерин) до та після лікування представлений у таблиці 4 і 5.

До лікування достовірні кореляційні зв'язки були між СОД та ЛПВЩ, ЛПнЩ і холестерином; холестерином з СОД і каталазою; лПВЩ з СОД і ДК; SН-гр з ТГ, ЛПНЩ; ДК з ЛПНЩ; з МДА і показниками ліпідограми не було жодних вірогідних кореляційних зв'язків.

Кореляційні зв'язки були після лікування між СОД і ХС, лПНЩ та ТГ. Каталаза мала кореляційні зв'язки з холестерином. SН-групи та МДА корелювали з ТГ і лПВЩ. Показник ДК мав кореляційні зв'язки з ХС та ТГ.

Таблиця 4. Показники кореляції між показниками ПОЛ (ДК, МДА), АОЗ (SH-групи, СОД, каталаза) та даними ліпідограми (ЛПВЩ, ЛПНЩ, ТГ, холестерин) до лікування

\begin{tabular}{|l|c|c|c|c|}
\hline \multicolumn{1}{|c|}{ Показник } & ТГ & Холестерин & ЛПВП & ЛПНП \\
\hline СОД & 0,07 & $-0,34^{*}$ & $0,26^{*}$ & $0,35^{*}$ \\
\hline Каталаза & 0,03 & $0,22^{*}$ & $-0,13$ & $0,20^{*}$ \\
\hline SН-гр & $-0,22^{*}$ & 0,15 & 0,06 & $0,18^{*}$ \\
\hline МДА & 0,06 & 0,16 & $-0,07$ & 0,14 \\
\hline ДК & 0,02 & 0,14 & $-0,24^{*}$ & 0,15 \\
\hline
\end{tabular}

Примітка. 1. * - наявність кореляційних зв'язків.

Таблиця 5. Показники кореляції між показниками ПОЛ (ДК, МДА), АОЗ (SН-групи, СОД, каталаза) та даними ліпідограми (ЛПВЩ, ЛПнЩ, ТГ, холестерин) після лікування

\begin{tabular}{|l|c|c|c|c|}
\hline \multicolumn{1}{|c|}{ Показник } & ТГ & Холестерин & ЛПВП & ЛПНП \\
\hline СОД & $-0,19^{*}$ & $-0,31^{*}$ & 0,10 & $-0,24^{*}$ \\
\hline Каталаза & 0,13 & $0,21^{*}$ & $-0,04$ & 0,16 \\
\hline SН-гр & $-0,21^{*}$ & $-0,12$ & $0,18^{*}$ & $-0,08$ \\
\hline МДА & $0,22^{*}$ & 0,10 & $-0,02$ & 0,04 \\
\hline ДК & $0,20^{*}$ & $0,22^{*}$ & $-0,15$ & 0,16 \\
\hline
\end{tabular}

Примітка. 1. * - наявність кореляційних зв'язків.

Висновки. 1. У хворих з діабетичною полінейропатією та дисліпідемією діагностували підвищення ПОЛ та зниження показників АОЗ.

2. Лікування із включенням препарату Келтікан або світлотерапевтичних процедур має позитивний вплив на рівні ДК та SH-груп.
3. Комбінована терапія з одночасним включенням поляризуючого світла та препарату Келтікан сприяла достовірному зниженню МДА, ДК та підвищенню СОД, каталази та SH-груп. 
Огляди літератури, оригінальні дослідження, погляд на проблему, ювілеї

\section{ЛІТЕРАТУРА}

1. Giacco F. Oxidative stress and diabetic complications [Text] / F. Giacco, M. Brownlee // Cir. Res. - 2010. - Vol. 107.P. $1058-1070$.

2. Oxidative stress and stress-activated signaling pathways: a unifying hypothesis of type 2 diabetes [Text] / J. L. Evans, I. D. Goldfine, B. A. Maddux, G. M. Grodsky // Endocrine Rev. - 2002. - Vol. 23, No. 5. - P. 599-622.

3. Oxidative stress in the pathogenesis of diabetic neuropathy [Text] / A. M. Vincent, J.W. Russel, P. Low, E. L. Feldman // Endocrinol. Rev. - 2004. - Vol. 25, No. 4. P. 612-628

4. Попова Т. Н. Интенсивность свободнорадикальных процессов в печени крыс при сахарном диабете 2 типа и введении эпифамина / Т. Н. Попова, А. А. Агарков, А. Н. Веревкин // Экспериментальные статьи. 2013. - № 4 (19). - C. 129-134.

5. Comparative characteristics of antioxidant status in women with diabetes type 2 of different age groups / O. G. Ishonina, Z. I. Mikashinovich, E. V. Olempieva, T. D. Kovalenko // Adv. Gerontol. - 2011. - No. 24 (4). - P. 645-649.

6. Бардымова Т. П. Перекисное окисление липидов, антиоксидантная система у больных сахарным диабетом II типа // Т. П. Бардымова, Л. И. Колесникова, В. А. Петрова // Бюллетень ВСНЦ СО РАМН. - 2005. № 6 (44). - С. 50-54.

7. Сорокина Ю. А. Коэффициенты окислительного стресса как способ персонифицирования фармакотерапии в дебюте СД 2 типа / Ю. А. Сорокина, Л. В. Ловцова // Universum: Медицина и фармакология: Эл. научн. журн. - 2015. - № 1 (14). - Режим доступу: http://7universum.com/ ru/med/archive/item/1868

8. Балаболкин М. И. Лечение сахарного диабета и его осложнений // М. И. Балаболкин, Е. М. Клебанова, В. М. Креминская. - М. : Медицина, 2005. - 325 с.

9. Балаболкин М. И. Роль гликирования белков, окислительного стресса в патогенезе сосудистых осложнений при сахарном диабете / М. И. Балаболкин // Сахарный диабет. - 2002. - № 4. - С. 5-16.

10. Занозина О. В. «Порочный круг» взаимосвязи перекисного окисления липидов и окислительной модификации белков у больных сахарным диабетом 2 типа / О. В. Занозина, Ю. А. Сорокина, Н. Н. Боровков, Т. Г. Щербатюк // Медицинский альманах. - 2013. - № 6. C. $167-170$.

11. Занозина О. В. Роль окислительного стресса в развитии и прогрессировании поздних осложнений сахарного диабета 2 типа. Возможности антиоксидантной терапии : автореф. дисс. на соискание ученой степени докт. мед. наук. - Н. Новгород, 2010.

12. Занозина О. В. Роль окислительного стресса в развитии и прогрессировании поздних осложнений сахарного диабета 2-го типа. Возможности антиоксидантной терапии // Международный эндокринологический журнал. - 2010. - № 7 (31).

13. Sharma R.B., Alonso L.C. Lipotoxicity in the pancreatic beta cell: not just survival and function, but proliferation as well? // Curr. Diab. Rep. - 2014. - Vol. 14(6). P. 492. doi: 10.1007/ s11892-014-0492-2.

14. Горюшкина О. А. Антиоксидантная терапия в коррекции оксидативного стресса у больных ишемической болезнью сердца с сахарным диабетом 2-го типа / О.А.Горюшкина, Е.М.Васильева // Вестник новых медицинских технологий. - 2013. - Т. XX, № 2. - С. 156.

15. HDL lipid composition is profoundly altered in patients with type 2 diabetes and atherosclerotic vascular disease / C. Morgantini, D. Meriwether, S. Baldi [et al.] // Nutr. Metab. Cardiovasc. Dis. - 2014. - Vol. 24 (6). - P. 594599. doi: 10.1016/j. numecd.2013.12.011.

16. The ways of improvement of the life quality of the patients with diabetic neuropathy / L. P. Martynyuk, M. I. Shved, N. R. Makarchuk, V. I. Chernetskyi // European Scientific Journal. - 2018. - No. 1 (29). - P. 39-41.

17. Швед М. І. Клінічна ефективність використання комбінованого амінокислотного комплексу в лікуванні хворих на діабетичну полінейропатію / М.І. Швед, Н. Р. Макарчук, Л. П. Мартинюк // Журнал Вісник наукових досліджень. - 2017. - № 3. - С. 60-63.

18. Наказ МОЗ України від 21.12.2012 №1118 «Про затвердження медико-технологічних документів зі стандартизацією медичної допомоги при цукровому діабеті 2 типу» : наказ МОЗ України. - Режим доступу:// www/moz.qov.ua/ua/portal/dn_20121221_1118.html

\section{REFERENCES}

1. Giacco, F., M. Brownlee. (2010) Oxidative stress and diabetic complications. Cir. Res., 107, 1058-1070.

2. Evans, J.L., Goldfine, I.D., Maddux, B.A., \& Grodsky, G.M. (2002). Oxidative stress and stress-activated signaling pathways: a unifying hypothesis of type 2 diabetes. Endocrine Rev., 23, 5, 599-622.

3. Vincent, A.M., Russel, J.W., Low, P., \& Feldman, E.L. (2004). Oxidative stress in the pathogenesis of diabetic neuropathy. Endocrinol., 25, 4, 612-628.

4. Popova, T.N., Aharkov, A.A., \& Verevkin, A.N. (2013). Intensivnost svobodnoradikalnykh protsessov v pecheni krys pri sakharnom diabete 2 tipa i vvedenii epifamina [Intensity of free radical processes in liver of rats with type 2 diabetes mellitus and administration of epifamine]. Eksperementalni statti - Experimental Articles, 4 (19), 129-134 [in Russian].

5. Ishonina, O.G., Mikashinovich, Z.I., Olempieva, E.V., \& Kovalenko, T.D. (2011). Comparative characteristics of antioxidant status in women with diabetes type 2 of different age groups. Adv. Gerontol, 24 (4), 645-649.

6. Bardymova, T.P., Kolesnikova, L.I., \& Petrova, V.A. (2005). Perekisnoe okisleniye lipidov, antioksidantnaya sistema u bolnykh sakharnym diabetom II tipa [Peroxide oxidation of lipids, antioxidant system in patients with type II diabetes mellitus]. Byulleten VSNTS SO RAMN - Journal of VSNTS SO RAMN, 6 (44), 50-54 [in Russian].

7. Sorokina, Yu.A., \& Lovtsova, L.V. (2015). Koefitsiyent okislitelnogo stressa kak sposob personifitsirovaniya farmakoterapii v debyute SD 2 tipa [Oxidizing stress factors as a method of personification of pharmacotherapy in the type 2]. Universum: Meditsina i farmakologiya: El. 
Огляди літератури, оригінальні дослідження, погляд на проблему, ювілеї

nauchn. Zhurn. - Universum: Medicine and Pharmacology: Electronic Scientific Journal, 1 (14). Retrieved from: http://7universum.com/ ru/med/archive/item/1868 [in Russian].

8. Balabolkin, M.I., Klebanova, E.M., \& Kreminskaya, V.M. (2005). Lecheniye sakharnogo diabeta i ego oslozhneniy [Treatment of diabetes mellitus and its complications]. Moscow: Meditsina [in Russian].

9. Balabolkin, M.I. (2002). Rol glikirovaniya belkov, okislitelnogo stressa $v$ patogeneze sosudistykh oslozhneniy pri sakharnom diabete [The role of glycation of proteins, oxidative stress in the pathogenesis of vascular complications in diabetes mellitus]. Sakharnyy diabet-Diabetes Mellitus, 4, 5-16 [in Russian].

10. Zanozina, O.V., Sorokina, A.N., Borovkov, N.N., \& Shcherbatyuk, T.G. (2013). "Porochyy krug" vzamosvyazi perekisnogo okisleniya lipidov i okislitelnoy modifikatsii belkov u bolnykh sakharnym diabetom 2 tipa ["Defective circle" of interconnections of lipid peroxidation and oxidative modification of proteins in patients with type 2 diabetes mellitus]. Meditsinskiy almanakh - Medical Almanac, 6, 167-170 [in Russian].

11. Zanozina, O.V. (2010). Rol okislytelnogo stressa v razvitii i progressirovanii pozdnikh oslozhneniy sakharnogo diabeta 2 tipa. Vozmozhnosti antioksydantnoy terapii [The role of oxidative stress in the development and progression of late complications of type 2 diabetes. Possibilities of antioxidant therapy]. Doctor's Extended abstract. N. Novgorod [in Russian].

12. Zanozina, O.V. (2010). Rol okislitelnogo stressa v razvitii i progressirovanii pozdnikh oslozhneniy sakharnogo diabeta 2-go tipa. Vozmozhnosti antioksydantnoy terapii [The role of oxidative stress in the development and progression of late complications of type 2 diabetes mellitus. Antioxidant therapy possibilities]. Mizhnarodnyi endokrynolohichnyi zhurnal - International Endocrinological Journal, 7 (31) [in Russian].
13. Sharma, R.B., \& Alonso, L.C. (2014). Lipotoxicity in the pancreatic beta cell: not just survival and function, but proliferation as well? Curr. Diab. Rep., 14 (6), 492. doi: 10.1007/s11892-014-0492-2.

14. Horyushkina, O.A., \& Vasilyeva, E.M. (2013). Antioksidantnaya terapiya v korrektsii oksidativnogo stressa u bolnykh ishemicheskoy boleznyu serdtsa s sakharnym diabetom 2-go tipa [Antioxidant therapy in the correction of oxidative stress in patients with ischemic heart disease with type 2 diabetes mellitus]. Vestnik novykh meditsynskikh tekhnologiy - Journal of New Medical Technologies, $X X(2), 156$ [in Russian].

15. Morgantini, C., Meriwether, D., \& Baldi, S. (2014). HDL lipid composition is profoundly altered in patients with type 2 diabetes and atherosclerotic vascular disease. Nutr. Metab. Cardiovasc. Dis. 24 (6), 594-599. doi: 10.1016/j. numecd.2013.12.011.

16. Martynyuk, L.P., Shved, M.I. Makarchuk, N.R., \& Chernetskyi, V.I. (2018). The ways of improvement of the life quality of the patients with diabetic neuropathy. European Scientific Journal, 1 (29), 39-41.

17. Shved, M.I., Makarchuk, N.R., \& Martyniuk, L.P. (2017). Klinichna efektyvnist vykorystannia kombinovanoho aminokyslotnoho kompleksu v likuvanni khvorykh na diabetychnu polineiropatiiu [Clinical efficiency of using the combined amino acid complex in the treatment of patients with diabetic polyneuropathy]. Zhurnal Visnyk naukovykh doslidzhenJournal of Scientific Researches, 3, 60-63 [in Ukrainian].

18. Nakaz MOZ Ukrainy vid 21.12.2012 №1118 “Pro zatverdzhennia medyko-tekhnolohichnykh dokumentiv zi standartyzatsiieiu medychnoi dopomohy pry tsukrovomu diabeti 2 typu" [Order of the Ministry of Health of Ukraine dated December 21, 2012 No. 1118 "On Approval of Medical-Technological Documents with Standardization of Medical Assistance in Type 2 Diabetes" Order of the Ministry of Health of Ukraine]. Retrieved from: //www/moz.qov.ua/ua/ portal/dn_20121221_1118.html [in Ukrainian].

\title{
ВЛИЯНИЕ КЕЛТИКАНА И ПОЛЯРИЗУЮЩЕГО СВЕТА НА ПОКАЗАТЕЛИ ПЕРЕКИСНОГО ОКИСЛЕНИЯ ЛИПИДОВ И АНТИОКСИДАНТНОЙ ЗАЩИТЫ У БОЛЬНЫХ САХАРНЫМ ДИАБЕТОМ 2 ТИПА С ДИАБЕТИЧЕСКОЙ ПОЛИНЕЙРОПАТИЕЙ И ДИСЛИПИДЕМИЕЙ
}

\section{๑Л. П. Мартынюк, Н. Р. Макарчук}

\author{
ГУВЗ «Тернопольский государственный медицинский университет имени И. Я. Горбачевского \\ МЗ Украины»
}

PЕЗЮМЕ. У больных сахарным диабетом (СД) 2 типа происходит нарушение процессов перекисного окисления липидов, в результате чего нарушается нормальное функционирование мембранных структур клеток, усиливается их деструкция, а это может быть фактором прогрессирования такого осложнения, как диабетическая полинейропатия (ДПН).

Целью исследования было изучение влияния комплексного лечения путем включения препарата Келтикан и поляризующего света на показатели пОЛ и АОЗ у больных сахарным диабетом 2 типа с диабетической полинейропатией и дислипидемией.

Материал и методы. Обследовано 130 больных СД 2 типа, осложненным диабетической полинейропатией. Пациенты были распределении на 4 группы: в 1 группу вошло 32 пациента, которые получали стандартное лечение, 32 больных 2 группы дополнительно получали келтикан по 1 капсуле три раза в сутки в течение месяца. 35 диабетикам 3 группы дополнительно были назначены 12 лечебных процедур поляризующим светом. 31 пациент 4 группы, помимо стандартного лечения, получал келтикан и курс светотерапевтических процедур поляризующим светом одновременно. 
Огляди літератури, оригінальні дослідження, погляд на проблему, ювілеї

Состояние ПОЛ оценивали по содержанию диеновых конъюгатов (ДК) и малонового диальдегида (МДА). Активность антиоксидантной защиты (АОЗ) изучали по концентрации супероксиддисмутазы (СОД), каталазы и глутатиона восстановленого (SH-группа).

Результаты. Включение в стандартное лечение ДПН келтикана и поляризующего света имеет более выраженное влияние на показатели ПОЛ и АОЗ, по сравнению со стандартным лечением. Результаты липидограммы наиболее близки к целевому уровню под влиянием лечения в 4 группы.

Для оценки состояния липидного обмена определяли уровни ХС (холестерина), фракций лпВП (липопротеидов высокой плотности), лПнП (липопротеидов низкой плотности) и ТГ (триглицеридов).

Вывод. Включение в стандартную терапию дПн у больных сахарным диабетом 2 типа и дислипидемией препарата Келтикан и светотерапевтических процедур имело корректирующее влияние на показатели пол и AO3.

КЛЮчЕВЫЕ слОВА: диабетическая полинейропатия; оксидативный стресс; липидный обмен; келтикан; поляризованный свет.

\section{EFFECT OF KELTICAN AND POLARIZING LIGHT ON LIPID PEROXIDATION AND ANTIOXIDANT DEFENSES IN TYPE 2 DIABETES MELLITUS WITH DIABETIC POLYNEUROPATHY AND DYSLIPIDEMIA}

\section{Horbachevsky Ternopil State Medical University}

SUMMARY. Patients with type 2 diabetes mellitus (DM) suffer from dysfunction of lipid peroxidation processes, resulting in abnormal functioning of cell membrane structures, which leads to their increased destruction, and may be a factor in the progression of diabetic polyneuropathy (DPN) complication.

The aim of the study was to learn the effects of complex treatment with incorportion of the Keltican drug and polarizing light on LPO and AOP indicators in patients with type 2 diabetes with diabetic polyneuropathy and dyslipidemia.

Material and Methods. 130 patients with type 2 diabetes, complicated by diabetic polyneuropathy were examined. Patients were divided into 4 groups: 32 patients in group 1 received standard treatment, 32 patients in group 2 additionally received 1 capsule of Keltican three times a day for one month. For 35 diabetics of group 3, 12 therapeutic procedures were additionally assigned with polarizing light. 31 patients in the group 4, in addition to standard treatment, received Keltican combined with polarizing light therapy course.

The state of LPO was assessed by the content of conjugated dienes and malondialdehyde (MDA). The antioxidant protection (AOP) activity was studied by concentration of superoxide dismutase (SOD), catalase and glutathione reductase (SH-group).

Cholesterol levels, as well as fractions of HDL (high density lipoprotein), LDL (low density lipoprotein) and TG (triglycerides) were determined to assess lipid metabolism.

Results. Inclusion of Keltican and polarizing light in the standard treatment of DPN has a more pronounced effect on LPO and AOP compared to standard treatment. The results of lipidograms are most closely related to the target level under the influence of treatment in the group 4.

Conclusion. Inclusion of the drug Keltican and light therapeutic procedures in the standard therapy of DPN in patients with type 2 diabetes and dyslipidemia had an adjusting impact on LPO and AOP indicators.

KEY WORDS: diabetic polyneuropathy; oxidative stress; lipid metabolism; keltican; polarizing light.

Отримано 19.07.2018 